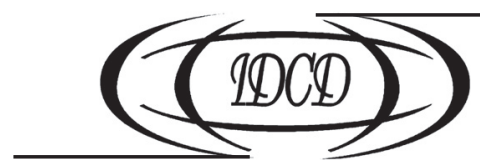

https://doi.org/10.15407/dse2019.02.178

УДК 519.7

JEL CLASSIFICATION: J11, J23, J24

\title{
І.Л. ТАТОМИР
}

канд. екон. наук., доц. каф. економіки та менеджменту

Дрогобицький державний педагогічний

університет імені Івана Франка

82100, Україна, м. Дрогобич, вул. Стрийська, 3

E-mail: Tatomur@gmail.com

ORCID 0000-0002-3274-7083

\section{ЗАЙНЯТІСТЬ ТА ОСВІТНЯ ПОЛІТИКА В ЕПОХУ ШТУЧНОГО ІНТЕЛЕКТУ Й РОБОТОТЕХНІКИ}

Мета статті - розглянути результати впливу використання штучного інтелекту на зайнятість населення та зміну професійних розподілів, обгрунтувати роль освіти у цих процесах та запропонувати иляхи мінімізації негативних наслідків ризиків цих процесів для національного ринку праці. Проаналізовано песимістичні та оптимістичні прогнози економістів щодо подальшої ролі штучного інтелекту у процесах автоматизації. Обгрунтовано вплив сучасних мегатрендів на глобальний ринок праці, визначено сфери, які зазнають найбільшого впливу робототехніки. Запропоновано напрями модернізаціі системи освіти на загальнодержавному рівні з метою забезпечення конкурентоспроможності робочої сили та їі швидкої адаптації до змін попиту та пропозиції на ринку праці. Мова йде про реорганізацію системи освіти з обов'язковим упровадженням у навчальні плани дисциплін IT-характеру, підтримання ініціатив з популяризації курсів Coursera, Edx, Udemy, Udasity та інших провайдерів. Це дасть змогу навчати українських студентів за світовими інноваційними програмами, збільшити кількість навчальних закладів за професійно-технічним спрямуванням та їх популярність серед молоді, впроваджувати активні системи отримання освіти безспосередньо на виробництві. Рекомендовано створювати профільні інститути та кафедри штучного інтелекту, робототехніки і машинознавства, які б тісно співпрацювали зі школами і приватними технохабами для підвищення рівня підготовки студентів, запровадження стипендій для обдарованої молоді та викладачів, які займаються дослідженнями у сфері штучного інтелекту.

Ключові слова: штучний інтелект, професії-«пенсіонери», щільність робототехніки, клас непотрібних людей, атлас професій.

\section{И.Л. Татомир}

канд. экон. н., доц. каф. экономики и менеджмента

Дрогобычский государственный педагогический

университет имени Ивана Франко

82100, Украина, г. Дрогобыч, ул. Стрыйская, 3

E-mail: Tatomur@gmail.com

ORCID 0000-0002-3274-7083 


\title{
ЗАНЯТОСТЬ И ОБРАЗОВАТЕЛЬНАЯ ПОЛИТИКА \\ В ЭПОХУ ИСКУССТВЕННОГО ИНТЕЛЛЕКТА И РОБОТОТЕХНИКИ
}

Проанализированы пессимистичные и оптимистичные прогнозы экономистов о дальнейшей роли искусственного интеллекта в процессах автоматизации. Обосновано влияние современных мегатрендов на глобальный рынок труда и определены сферы, испытывающие наибольшее влияние робототехники. Предложены направления модернизации системы образования на общегосударственном уровне с иелью обеспечения конкурентоспособности рабочей силы и ее быстрой адаптации к изменениям спроса и предложения на рынке труда. Речь идет о реорганизации системы начального образования с обязательным внедрением в учебные планы дисциплин ИТ-характера, поддержание инициатив по популяризации курсов Coursera, Edx, Udemy, Udasity и других провайдеров, что позволило бы обучать украинских студентов по мировым инновационным программам, увеличение количества учебных заведений по профессионально-техническим направлением, внедрение активных систем переобучения на производстве. Рекомендовано создание профильных институтов и кафедр искусственного интеллекта, робототехники и машиноведения, которые тесно сотрудничали бы со школами и частными технохабамии для повышения уровня подготовки студентов, организации стипендий для одаренной молодежи и преподавателей, занимающихся исследованиями в области искусственного интеллекта.

Ключевые слова: искусственный интеллект, профессии-«пенсионеры», плотность робототехники, класс ненужных людей, атлас профессий.

\author{
I. L. Tatomur \\ PhD in Economics, Associate Professor of departments of Economics and Management \\ Drohobych State Pedagogical University after Ivan Franko \\ 82100, Ukraine, Drohobych, Ivan Franko Str., 24 \\ E-mail: Tatomur@gmail.com \\ ORCID 0000-0002-3274-7083
}

\section{EMPLOYMENT AND EDUCATION POLICIES IN THE ERA OF ARTIFICIAL INTELLIGENCE AND ROBOTICS}

The paper analyzes the pessimistic and optimistic predictions of economists regarding the further role of artificial intelligence in automation processes. The influence of modern mega-trends on the global labor market is substantiated and the areas that are most affected by robotics are identified. The directions of modernization of the education system at the national level are proposed in order to ensure the competitiveness of the labor force and its rapid adaptation to changes in demand and supply in the labor market. It is a question of reorganizing the primary education system with the mandatory introduction of IT-disciplines into curricula, supporting initiatives to promote courses Coursera, Edx, Udemy, Udasity and other providers, which would allow Ukrainian students to study on world programs, increase the number of educational institutions according to the vocational and technical direction, the introduction of active retraining systems at work. An increase in state funding for research on artificial intelligence, the use of new combinations of public-private and academic cooperation, and the provision of various types of fiscal incentives to support technological start-ups, which are designed to improve production processes, are seen as needed. A digital education and cooperation with European universities in the field of artificial intelligence for a better exchange of work, informing young people and the academic community about the educational initiatives of technology companies, organizing summer schools for the study of IT technologies and the participation of our students and students in such projects for the border. It would be desirable to create specialized institutes and departments of artificial intelligence, robotics and machine science, which would closely cooperate with schools and private techno-architects, inviting to cooperation specialists who have experience in the IT industry, in the role of mentors, to help students in choosing interesting topics for educational projects, the introduction of scholarships for gifted youth and teachers engaged in research in the field of artificial intelligence.

Keywords: artificial intelligence, occupations retired, density of robotics, class of unnecessary people, atlas of professions.

Постановка проблеми та актуальність теми. Цифрова революція позначилась на професійно-кваліфікаційній структурі попиту та пропозиції на ринку праці та зумовила потребу у трансформації освітнього простору. Технологічні зміни призвели до того, 
що конкуренція за доступ до інноваційних технологій створила нові механізми експлуатації жителів країн, що розвиваються, та зниження рівня продуктивності їхньої праці. Цифровізація масиву даних, доповнена реальність, технології візуального трансферу та штучний інтелект (ШІ) змусили роботодавців переглянути традиційні підходи до підбору персоналу й організації робочих місць. У розвинутих країнах близько 40 \% із них уже відчули суттєві економічні переваги автоматизації робіт середньої складності і скорочення унаслідок цього частини працівників. Наприклад, оперування роботизованими системами коштує в США приблизно 10-20 доларів на годину, що є нижчим за середню заробітну платню у виробництві [1, с. 52]. Водночас використання і обслуговування нових технологій зумовило потребу підвищення рівня компетенції працівників, більшість з яких не готові до змін а над ринком праці нависла загроза поляризації структури зайнятості та появи професій-«пенсіонерів» ${ }^{1}$ і класу непотрібних людей ${ }^{2}$.

Аналіз останніх досліджень та публікацій. Потенційна заміна працівників автоматизованими машинами привернула увагу науковців, роботодавців, політиків та експертів з цих питань. Наприклад, В. Мулявка (V. Mulyavska) [2] розглянула механізми експлуатації нових технологій, ризики автоматизації праці в суспільствах, що розвиваються, та перспективи для суспільств периферії. У роботах I. Новак (I. Novak) [3] показано, як ШІ, віртуальна реальність й великі дані трансформують обличчя ринку праці і визначено стратегічні орієнтири зайнятості.

Про оптимістичний і тривожний сценарій впливу ШІ на ринок праці і відповіді вищої освіти заговорили і зарубіжні дослідники Б. Сміт (В. Smith), Г. Шум (H. Shum) [1], Е. Бріньолфссон (Е. Brignolpson), Е. МакАфі (А. McAfee) [4], М. Форд (М. Ford) [5] та ін. Прихильники песимістичного сценарію розвитку [4, 5], оцінюючи маргінальний вплив використання ШІ на продуктивність праці, прогнозують масове безробіття, бідність і загострення соціальної напруги. На їхнє переконання, інтеграція технічних Cyber фізичних систем призведе до значної економії витрат на оплату праці та відмирання звичних професій, цикли яких скоротяться до 3-5 років. Як тільки для нової спеціальності буде створено алгоритм, виконання її переходитиме до ро́бота. Освоєння всього невідомого стане новим кар’єрним викликом століття.

Прихильники оптимістичного сценарію [1, 2] не бачать приводу для паніки, адже економіка автоматизується безперервно: зникнення однієї частини робочих місць відбуватиметься одночасно з їх виникненням за іншими професійними та секторальними напрямками. Робота буде позбавлена рутинного характеру, стане цікавішою та творчою, формуватиметься не протистояння людей і машин, а їх взаємодопомога. Ця дискусія змушує заклади вищої освіти та підприємців шукати освітні рішення і таланти для нових цифрових ролей.

Економісти [3, 4, 5], наполягають на потребі розвитку цифрової грамотності, наданні престижнішого статусу професійно-технічній освіті й розробці адаптивних програм перенавчання для дорослого населення.

Мета статті - розглянути результати впливу використання штучного інтелекту на зайнятість населення та зміну професійних розподілів, обгрунтувати роль освіти у цих процесах й запропонувати шляхи мінімізації негативних наслідків формують цих процесів, для національного ринку праці.

\footnotetext{
${ }^{1}$ Професії пенсіонери - професії, що ризикують зникнути або ті, де працівники можуть бути замінені ро́ботами, комп'ютерними програмами та іншими автоматичними рішеннями.

2 Клас непотрібних людей - особи, які через небажання чи певні обставини не можуть опанувати затребувані вимогами часу професії.
} 
Новизною статті є обгрунтування можливих шляхів адаптації українського ринку праці до впровадження автоматизованих систем у виробничі процеси.

Методологія дослідження. Методологічною базою дослідження став аналіз підходів вітчизняних і зарубіжних учених до вивчення потенційного довгострокового впливу автоматизації на національний ринок праці. Для визначення технічного потенціалу автоматизації світової економіки різних країн застосовано методи порівняльного аналізу, дані міжнародної консалтингової компанії McKinsey, торговопромислової асоціації робототехнічних галузей $(R I A)$, а також міжнародних звітів про майбутнє робочих місць для наочної зміни «атласу професій» ${ }^{3}$.

Виклад основного матеріалу. Нижче описано нові мега тренди, які змінили характер праці.

Великі дані, штучний інтелект та Інтернет речей; демографічні зміни; глобалізація і поляризація професійної структури допомогли зробити нестандартні завдання автоматизованими, змінивши характер діяльності більшості країн. У результаті деякі з них почали переживати «передчасну деіндустріалізацію». Ризик автоматизації зайнятості виявився найвищим у країнах із середнім рівнем доходу, де вимоги до роботи є менш складними, пізнавальними, творчими та міжособистісними. 3 найбільшим ризиком техногенного безробіття, частково через залежність від виробничих робочих місць, стикнулися Литва, Греція, Туреччина, Словаччина. Багатші країни (Норвегія, США та країни Південно-Східної Азіі) легше і швидше адаптувалися до змін через можливість постійного доступу до нових технологій. Тому найгірші умови склалися для працівників з середнім рівнем оплати праці та неповною вищою освітою. Так, у США майже 3 млн осіб працюють як офісні службовці, дуже вразливі до автоматизації. Переважна більшість - жінки, середній вік яких становить 43,5 роки, а середня зарплата - трохи більше 30 тис. доларів на рік. Менше п’ятої частини мають ступінь бакалавра. Якщо вони не зможуть отримати нові навички, додаткову освіту або кращі повноваження, то не зможуть і зберегти сучасний рівень життя [5, с. 79]. На думку експертів, саме низькокваліфіковані працівники нестимуть основний тягар втрат. Їх надлишок стане істотною загрозою для країн, що розвиваються. Питання їх інтеграції в структурно складний ринок праці залежатиме від попиту іноземних держав і соціальної системи безпеки, адже праця мігрантів обходиться роботодавцям поки що дешевше, ніж виробництво, експлуатація та обслуговування роботів.

Однак чимало науковців погоджуються, що більшість високоосвіченого населення даремно почувається в безпеці. Для ШІ період, коли людина повинна навчитися певному предмету, не є релевантним критерієм. Всі види робіт рутинного характеру можуть виконувати інтелектуальні машини. Навіть для високооплачуваних посад, для яких потрібне багаторічне навчання та дипломи про вищу освіту, часто можна знайти багато звичайних замін. Фахівці китайського інтернет-гіганта Tencent впевнені, що ро́боти здатні і на творчу працю. Нещодавно компанія представила світу ро́бота-журналіста, який всього за одну хвилину написав статтю про стан фінансового ринку [2]. У 2018 р. світ побачив перших ро́ботів, які вміють малювати картини, брати участь у судових процесах як адвокати, ставити діагнози пацієнтам тощо.

Демографічні зміни призвели до зниження частки працездатного населення в одних країнах (-8 \% в Японії, $-23 \%$ в Італії і Німеччині, $-21 \%$ в Китаї) і зростання в інших (+41\% в Саудівській Аравії, $+33 \%$ в Індіï, $+27 \%$ в Австралії, $+26 \%$ у Мексиці і Аргентині) [6, с. 5], спричинивши суттєвий перерозподіл праці і ресурсів між

\footnotetext{
3 «Атлас професій» - експертна дорожня карта професійного розвитку на найближчі десятиліття.
} 
Загальні обсяги робіт, які можна автоматизувати шляхом адаптації до пропонованих технологій

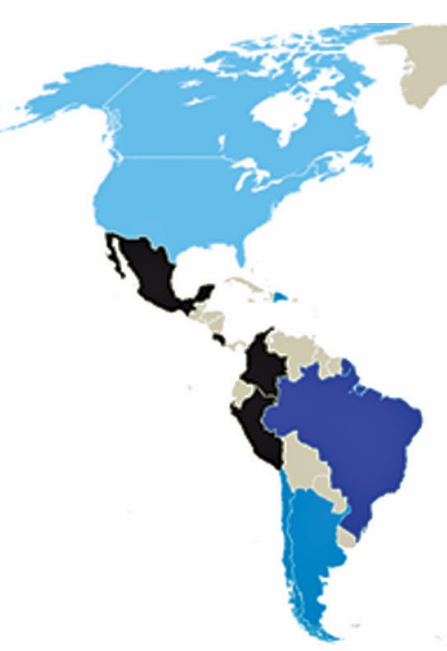

Заробітна плата пов'язана 3 технічною автоматичною діяльністю, трлн дол. США

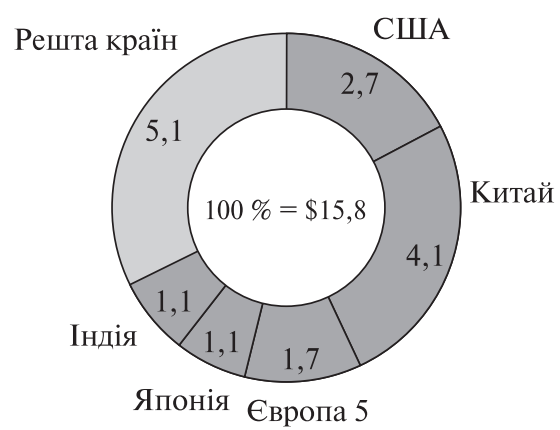

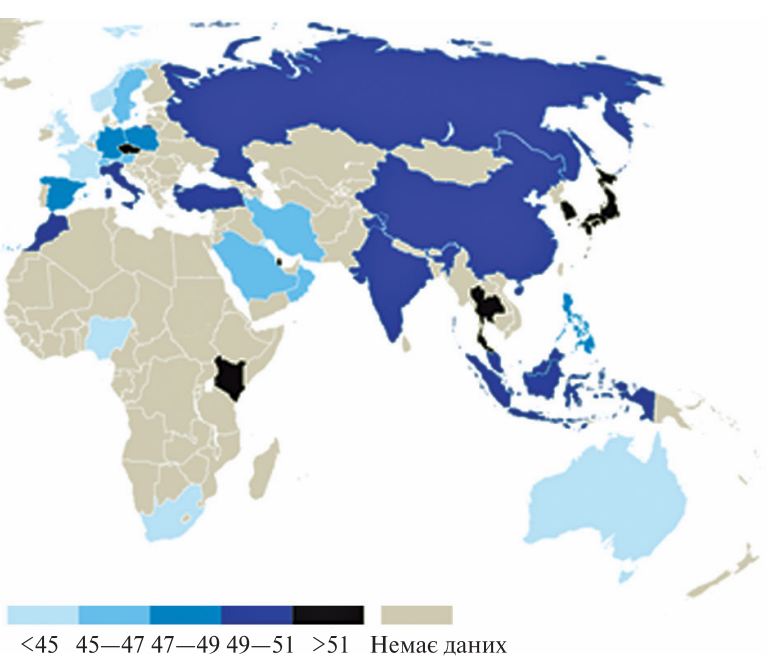

Робота пов'язана $з$ технічною автоматичною діяльністю, млн дол. США

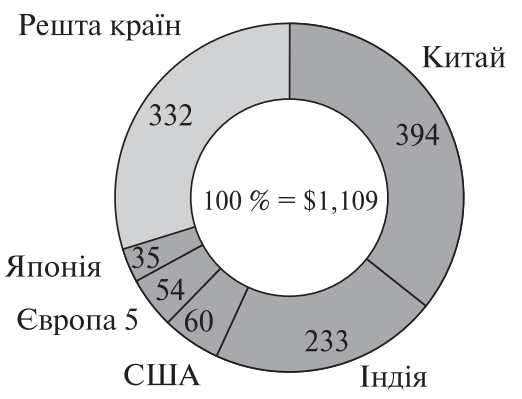

Потенціал автоматизації, \% Японія

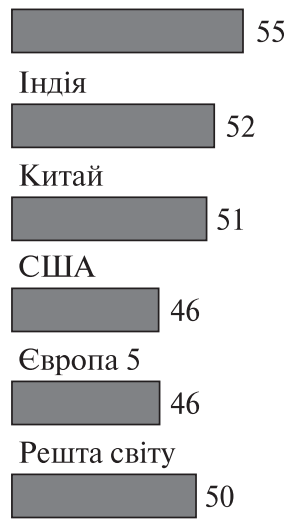

Рис. 1. Технічний потенціал автоматизації світової економіки в різних країнах

Примітка. Європа 5: Франція, Німеччина, Італія, Іспанія, Велика Британія.

Джерело: дані McKinsey \& Coтрапу [7, с. 7].

секторами та професіями. Країни з населенням, що старіє, почали активніше використовувати у виробничих процесах технології, а держави з молодою і збільшуваною робочою силою - потенціал демографічного дивіденду. Яскравим прикладом може слугувати Японія, де висока частка населення старшого віку і суворі закони в галузі трудової міграції змушують підприємців все більше використовувати ро́бототехніку, прискорюючи процес автоматизації.

Глобалізація зробила ринки праці більш взаємопов'язаними та сприяла прискореному темпу поширення технологій з використанням систем ШІ.

Поляризація професійної структури між високо- і низькокваліфікованими робочими місцями вплинула на нерівність розподілу доходів. 
Таблиця 1. Країни за часткою робочих місць з можливими високими темпами автоматизації для п'яти провідних галузей

\begin{tabular}{|c|c|c|c|c|c|}
\hline \multirow[t]{2}{*}{ Країна } & \multicolumn{5}{|c|}{$\begin{array}{c}\text { Частка робочих місць з можливими високими темпами автоматизації } \\
\text { для провідних галузей } \\
\end{array}$} \\
\hline & $\begin{array}{l}\text { Виробни- } \\
\text { цтво, \% }\end{array}$ & $\begin{array}{c}\text { Оптова та роз- } \\
\text { дрібна торгівля, \% }\end{array}$ & $\begin{array}{l}\text { Здоров'я людини і } \\
\text { соціальна робота, \% }\end{array}$ & $\begin{array}{l}\text { Осві- } \\
\text { та, } \%\end{array}$ & $\begin{array}{c}\text { Будів- } \\
\text { ництво, \% }\end{array}$ \\
\hline Словаччина & 58 & 43 & 34 & 14 & 42 \\
\hline Словенія & 57 & 35 & 31 & 13 & 53 \\
\hline Литва & 55 & 39 & 27 & 26 & 58 \\
\hline Чехія & 55 & 33 & 38 & 10 & 36 \\
\hline Італія & 55 & 35 & 29 & 17 & 44 \\
\hline США & 53 & 51 & 28 & 12 & 34 \\
\hline Франція & 53 & 41 & 29 & 17 & 41 \\
\hline Німеччина & 43 & 49 & 24 & 9 & 39 \\
\hline Австрія & 48 & 37 & 26 & 9 & 51 \\
\hline Іспанія & 45 & 35 & 26 & 8 & 42 \\
\hline Польща & 50 & 31 & 21 & 9 & 48 \\
\hline Туреччина & 45 & 26 & 36 & 8 & 40 \\
\hline Ірландія & 50 & 39 & 17 & 7 & 33 \\
\hline Нідерланди & 46 & 35 & 24 & 7 & 36 \\
\hline Велика Британія & 45 & 42 & 18 & 8 & 23 \\
\hline Бельгія & 45 & 28 & 19 & 10 & 43 \\
\hline Данія & 46 & 33 & 17 & 9 & 44 \\
\hline Ізраїль & 42 & 34 & 17 & 8 & 42 \\
\hline Сінгапур & 33 & 38 & 19 & 9 & 26 \\
\hline Норвегія & 33 & 34 & 16 & 6 & 35 \\
\hline Швеція & 45 & 26 & 22 & 4 & 28 \\
\hline Японія & 32 & 27 & 6 & 10 & 29 \\
\hline Греція & 35 & 23 & 20 & 3 & 25 \\
\hline Фінляндія & 41 & 22 & 9 & 4 & 35 \\
\hline Північна Корея & 31 & 24 & 12 & 6 & 31 \\
\hline
\end{tabular}

Джерело: складено автором на основі [8].

За оцінками експертів Оксфордського університету, які спеціалізуються на машинознавстві, машини замінять приблизно 47 \% наших робочих місць протягом двох наступних десятиліть, що призведе до зростання кількості та питомої ваги без робітного та економічно неактивного населення. У США автоматизація знищить приблизно 9,1 млн робочих місць до 2025 року. Очікувана кількість робочих місць, які потенційно можуть зникнути в Японії, становитиме 55 \%, в Індії 52, у Китаї 51 та у Сполучених Штатах 46 (рис. 1) [7, с. 5]. Нерівномірність автоматизованості робочих місць у різних країнах ілюструють рис. 1 та табл. 1. 


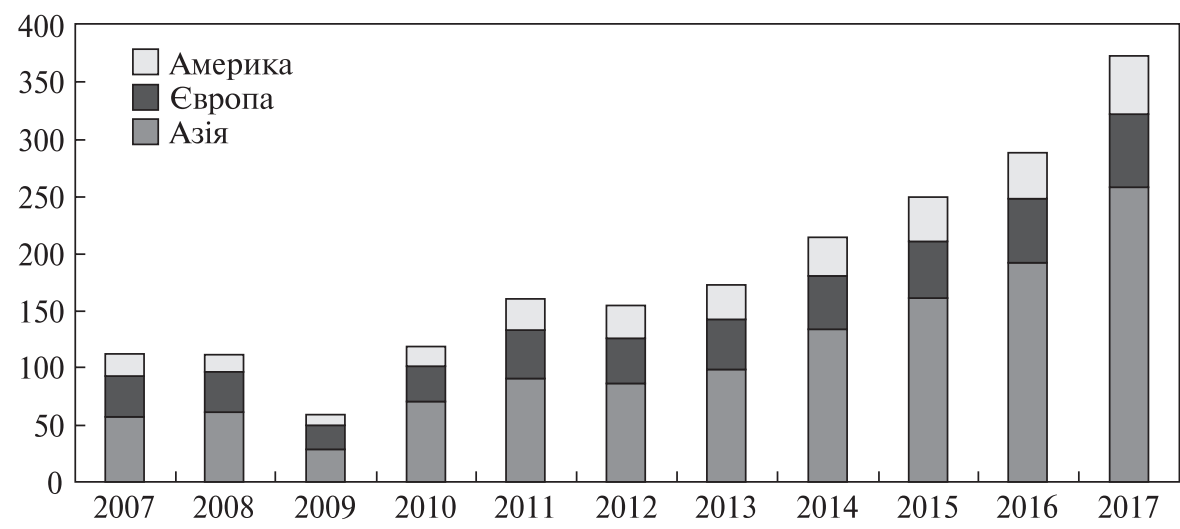

Рис. 2. Динаміка річних обсягів постачання промислових ро́ботів за регіонами світу, тис. одиниць

Джерело: побудовано автором на основі [9].

Дані Асоціації ро́бототехнічних виробників (RIA) [9], однієї з найбільших організацій, що займаються діяльністю в сфері автоматизованої роботи в Північній Америці, показують, наскільки поширені ро́боти можуть бути на робочому місці завтра. Рекорди з постачання робототехніки у всьому світі становив промисловий сектор: 294312 одиниць роботів 2016 року були відправлені клієнтам, що на $16 \%$ більше ніж з 2015. У 2017 році іх кількість досягла 380550 одиниць, що на $29 \%$ більше, ніж у попередньому (рис. 2). Безумовним лідером тут є країни Азії, зокрема Японія, яка лише у 2016 р. експортувала роботів для промислового сектору на суму 1,6 млрд дол. більше за п'ять найбільших експортерів (Німеччина, Франція, Італія, США, Південна Корея).

«Щільність робототехніки» як співвідношення роботів та людей, зайнятих у промисловості, визначає Міжнародна федерація робототехніки (IFR). Найвищий показник очікувано мають країни, які найактивніше продукують робототехніку (табл. 2). Угорі переліку IFR поставила Південну Корею, яка зуміла зберегти свій найвищий рейтинг з 2010 р. завдяки високому темпу зростання автоматизованих моделей. Наступний - Сінгапур, який закріпив за собою назву «успішного новатора робототехніки». Ще у п’ятірці лідерів - Німеччина, Японія та Швеція, які інтенсивно використовують основну частину роботів в електротехнічній, електронній та автомобільній промисловості. Найнижчий рівень «щільності робототехніки» притаманний Індії, Філіппінам і РФ, де на 10 тисяч робочих припадають три роботи.

Високий рівень «щільності робототехніки» доводить і той факт, що у країнах Азії з'являються повністю роботизовані виробництва. Так, у серпні 2015 р. у китайському місті Дунгуань відкрилася перша в історії роботизована фабрика з виробництва компонентів для стільникових телефонів. Власник фабрики компанія Changying Precision Technology замінила 650 співробітників на 60 роботизованих рук, тепер конвеєри працюють безперервно [11].

Негативні наслідки роботизації та автоматизації будуть відчуватися нерівномірно за професіями та сферами діяльності. Кращі робочі місця майбутнього потрапляють до одного сегмента технологічного обслуговування (рис. 3). Вчені-футурологи у «атлас професій» майбутнього включають такі види діяльності: сіті-фермер, проектувальник домашніх роботів, інформаційний стиліст, IT-генетик, експерт з майбутнього дитини, $I T$-медик тощо. Про існування таких фахів раніше годі було й подумати. 
Таблиця 2. Країни з найбільшою щільністю робототехніки, кількість промислових ро́ботів на 10 тис. виробничих працівників, 2016

\begin{tabular}{|c|c|c|c|}
\hline Країна & $\begin{array}{l}\text { Кількість промислових } \\
\text { ро́ботів на } 10 \text { тис. ви- } \\
\text { робничих працівників }\end{array}$ & Країна & $\begin{array}{c}\text { Кількість промислових } \\
\text { ро́ботів на } 10 \text { тис. вироб- } \\
\text { ничих працівників }\end{array}$ \\
\hline Південна Корея & 631 & Нідерланди & 153 \\
\hline Сінгапур & 488 & Канада & 145 \\
\hline Німеччина & 309 & Австрія & 144 \\
\hline Японія & 303 & Фінляндія & 138 \\
\hline Швеція & 223 & Словенія & 137 \\
\hline Данія & 211 & Словаччина & 135 \\
\hline США & 189 & Франція & 132 \\
\hline Італія & 185 & Швейцарія & 128 \\
\hline Бельгія & 184 & Чехія & 101 \\
\hline Тайвань & 177 & Австралія & 83 \\
\hline Іспанія & 160 & & \\
\hline
\end{tabular}

Джерело: складено за даними [10, с. 62].

Наприклад, цього року мережа LinkedIn оголосила вакансію на посаду тьютера для нейронної мережі - фахівця з різнопланового навчання ШІ. 2017 року порівняно з 2015 число користувачів LinkedIn, що додають навички в сфері Ш у своїх профілях, зросло на 190 \%. Це навички, необхідні для створення технологій Ш, які включають досвід у таких сферах, як нейронна мережа, глибоке вивчення та машинне навчання [13]. Затребувані математики, програмісти, компетентні статисти та фахівці з «кодування». Цінуватимуться так звані «універсальні солдати», особи, які володіють знаннями відразу в декількох галузях, добре знають свою роботу, не бояться виконувати складні завдання і регулярно покращують власні знання.

За даними Світового Економічного форуму, до 2030 року можуть зникнути або значно трансформуватись професії бухгалтера, копірайтера, бібліотекаря, юристаконсультанта, журналіста, перекладача, турагента, співробітників бек-офісів, сфери транспорту і логістики. Серед робітничих професій до категорії незатребуваних належатимуть охоронці, листоноші, оператори call-центрів, швеї, машинні оператори, гірники тощо. Така тенденція призведе до утворення класу непотрібних людей, частка яких у найближчому майбутньому збільшиться до 35-37 \% населення, а в деяких країнах - до 40 \%. Зараз у США налічується 10-12 \% непотрібних людей, в Ізраїлі - 8-9, в Південній Кореї, де існує культ роботи, - 1-2 \% [14].

За прогнозами економістів, до 2020 року середня заробітна плата у секторі ро́бототехніки збільшиться щонайменше на $60 \%$, однак більше третини наявних робочих місць залишатимуться вакантними через брак кваліфікованих працівників [15]. Міжнародні IT-гіганти Google, Facebook і Apple готові платити від 300 тис. дол. США на рік розробникам штучного інтелекту за умови, що вони є професіоналами в своїй галузі. Загалом річний оклад розробників ШІ може досягти 1 млн дол. США [16].

Ураховуючи попит на нові професії та невизначеність у традиційних секторах економіки через технічні зміни, актуалізується пошук нових освітніх рішень. Най- 


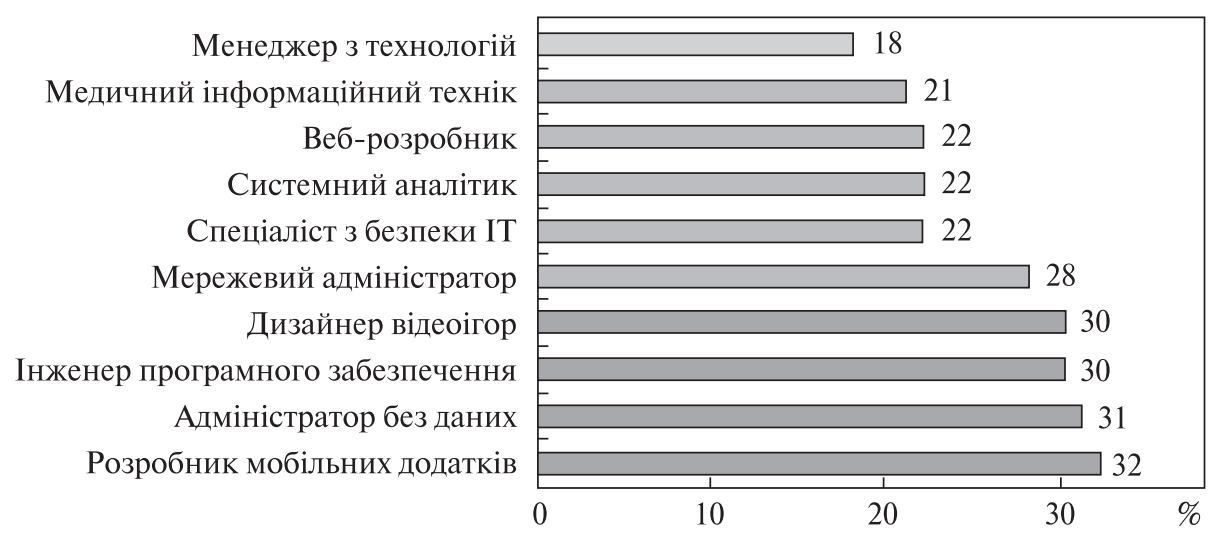

Рис. 3. Топ-10 професій майбутнього

Джерело: побудовано на основі даних [12].

кращу освіту надають країни, які впровадили обчислювальне мислення у початковій та середній школі. Студенти майбутнього повинні знати цю мову, навіть якщо вони оберуть будь-яку іншу галузь науки. Показовими у цьому відношенні є Японія, Китай та Ізраїль, де у шкільних програмах особливу увагу приділено вивченню інженерних технологій. Міністерства освіти цих країн дозволяють експериментувати з новими технологіями у класах з метою підготовки молоді, для якої робота з ШІ повинна стати запорукою їх майбутнього працевлаштування. Починаючи з 2019 р. уряд Японії пропонує впровадити вивчення програмування, а Китаю - курси з ШІ в початковій та середній школі. У ізраїльських школах учні, окрім стандартних дисциплін, слухають лекції про технології, IT-проекти, можливості їх реалізації та практичну цінність. До освітнього процесу адміністрація закладів залучає успішних стартаперів, керівників компаній і бізнесменів,У школах існують технологічні лабораторії з $3 D$-принтерами, ро́ботами, розумними дошками, що полегшує молоді адаптацію до технологічних нововведень. Особливу увагу уряди країн усе більше приділяють професійній технічній освіті, асигнуючи значні кошти у діяльність і зростання нових навчальних професійних закладів. Безумовним лідером тут є Китай з найбільшою в світі системою професійної освіти - 12300 коледжів, що пропонують близько 100000 спеціальностей [17]. Важливе значення для того, щоб люди могли пристосовуватись до нових технологій та ролей, матиме навчання протягом усього життя. Завдяки появі масових відкритих онлайн-курсів $(M B O K)^{4}$ та Інтернет-навчальних центрів (Coursera, Codeacademy, Big Data University ma edX Microsoft), де викладачами є професори і практики, успішні в тій чи іншій професії, якісна освіта стане ще доступнішою у кожному куточку світу. Найбільш затребуваними стануть проекти, за допомогою яких споживачі мають можливість швидко отримати нову кваліфікацію та конкретні навички, які згодом можна буде вдало конвертувати у дохід. Для прикладу, це можуть бути онлайн-курси, де навчають програмуванню, курси інтернет-маркетингу, створенню мобільних додатків та інтернет-магазинів тощо. Бум на віддалене навчання першочергово прослідковується серед людей, що вже певний період пропрацювали в професії і знають, які навички роботи й знання їм найбільше потрібні.

\footnotetext{
${ }^{4}$ МВOK - навчальні курси, розміщені онлайн і розраховані на всіх зацікавлених користувачів, що мають доступ до Інтернет, незалежно від віку, національності чи країни проживання.
} 
Технічні фірми з усього світу вживають заходів, щоб допомогти забезпечити майбутнє своїх нинішніх працівників. Хороший приклад - програма Amazon's Career Choice, яка заохочує співробітників до навчання навичкам майбутнього працевлаштування. HR експериментує з навчальними технологіями та хакатонами, щоб працівники постійно навчалися. Розширення ринку ділової освіти посилило і формування корпоративних навчальних інституцій - академій, інститутів, навчальних центрів тощо, діяльність яких має стратегічний характер, пов'язаний із бізнес-завданнями у сфері формування культури організації, кадрового резерву, оцінки ефективності персоналу та інвестицій, вкладених у його розвиток.

Намагається не відставати від технологічних новацій і український ринок праці. Україна, на жаль, не увійшла до переліку 40 країн, що використовують роботів у виробництві з показником 1 ро́бот на 20 тис. працівників (середньосвітовий показник - 74 ро́боти на 10 тис. осіб) [9] і займає 43 позицію серед 126 держав за розвитком інновацій згідно з індексом Блумберга. Український ринок робототехніки умовно можна розділити на два напрями: споживчий, де спостерігається стійкий попит на роботів-безпілотників і роботів-прибиральників, та промисловий - на якому щорічна реалізація роботів не перевищує кілька десятків, що свідчить про початковий попит промисловців на цю продукцію. Серед найбільших компаній-інтеграторів промислових ро́ботів і автоматизованих систем у виробничий процес можемо виокремити ТОВ «НВФ «Техвагонмаш» (м. Кременчук), АвтоЗАЗ (м. Запоріжжя), ТОВ «Центроспав-Україна» (м. Київ), ТОВ «Навко-Тех» (м. Київ) та ін. Перспективними напрямами для співпраці з іноземними компаніями експерти називають робототехніку, пов'язану з транспортом та логістикою, де українські виробники пропонують власні проекти. Типовими їх прикладами є ДК «Укроборонпром», який конструює техніку для оборонного комплексу, Drone. $U A$, що займається розробкою технологій для аграрної сфери, енергетики, геодезії і топографії, KNN Systems - компанія, що проектує рішення з роботизації процесів зварювання, фрезерування, плазмового різання і палетизації, компанія «Стандарт-ПАК», яка розробляє самохідні платформи, саморушні навантажувачі та ро́боти-буксири, запорізька компанія Інфоком ЛТД, що спеціалізується на безпілотних автомобілях, а також ряд інших компаній. Крім того, в Україні успішно функціонує декілька виробничих лабораторій у Дніпрі, Києві та Одесі - LabSeven, Ultimate Robotics, Mechatronics ROBOT Laboratory, Noosphere Engineering School, які працюють над комерційними замовленнями щодо реалізації роботизованих проектів у різних секторах економіки.

Ро́боти перестають бути просто технологічними цікавинками для українців. Найбільші вигоди від можливого впровадження автоматизованих систем отримає передовсім військовий сектор, використовуючи сучасні наземні роботизовані комплекси, наприклад, для розвідки. У найближчому майбутньому роботизовані пристрої зможуть вплинути і на українську медицину: це пристрої, які доповнять можливості хірурга, кіберпротези та біонічні лінзи. Враховуючи те, що технологічного оновлення потребує аграрний сектор, застосування високотехнологічних сервісів дасть змогу провадити моніторинг стану полів у реальному часі, виконувати автоматичне розрізнення культурних рослин і бур'янів, мінімізувати використання важкої людської фізичної праці. Від широкого асортименту інтегрованих рішень для інтелектуального управління виробництвом вигоди повинен отримати і промисловий сектор. Використання робототехніки та автоматизації має допомогти в морській розвідці нафти і газу, що може суттєво позначитися на ціні палива. 
Таблиця 3. Ризики та нові можливості, пов'язані з активізацією впровадження автоматизованих систем

\begin{tabular}{|c|c|c|}
\hline Роботодавці & Працівники & Держава \\
\hline \multicolumn{3}{|c|}{ Ризики } \\
\hline $\begin{array}{l}\text { МВOK - навчальні курси, роз- } \\
\text { міщені онлайн і розраховані на } \\
\text { всіх зацікавлених користувачів, } \\
\text { що мають доступ до Інтернет, } \\
\text { незалежно від віку, національ- } \\
\text { ності чи країни проживання }\end{array}$ & $\begin{array}{l}\text { Зростання потреби у перенавчан- } \\
\text { ні персоналу; } \\
\text { недостатньо висока надійність } \\
\text { роботизованих комплексів; } \\
\text { відсутність позитивного еконо- } \\
\text { мічного ефекту; } \\
\text { надання машинам певної вико- } \\
\text { навчої самостійності; } \\
\text { надмірне покладання на точність } \\
\text { та безвідмовність роботизованих } \\
\text { машин; } \\
\text { складність адаптувати роботи- } \\
\text { зовані комплекси для невеликих } \\
\text { підприємств }\end{array}$ & $\begin{array}{l}\text { Ручне управління поступово } \\
\text { втрачатиме значення на користь } \\
\text { технічних засобів; } \\
\text { невідповідність рівня підготовки й } \\
\text { брак потрібних навичок для роботи } \\
\text { на нових робочих місцях } \\
\text { робота потребуватиме творчого та } \\
\text { критичного мислення; } \\
\text { вивільнення певної частини праців- } \\
\text { ників та виникнення «технологіч- } \\
\text { ного безробіття»; } \\
\text { нерентабельність автоматизації } \\
\text { дешевої робочої сили; } \\
\text { виведення відносин найму на новий } \\
\text { рівень; } \\
\text { поширення різних видів прекарної } \\
\text { зайнятості; } \\
\text { послаблення ролі профспілок та } \\
\text { соціального захисту; } \\
\text { зниження фізичної та соціальної } \\
\text { активності людей; } \\
\text { збільшення соціального поділу на } \\
\text { професійні касти; } \\
\text { зниження вартості технологій при- } \\
\text { зведе до того, що автоматизація і } \\
\text { комп’ютеризація стануть вигідні- } \\
\text { шими за людську працю; } \\
\text { виникнення проблеми соціального } \\
\text { захисту в умовах можливого масо- } \\
\text { вого скорочення працівників } \\
\text { у наслідок упровадження роботизо- } \\
\text { ваної техніки }\end{array}$ \\
\hline \multicolumn{3}{|c|}{ Нові можливості } \\
\hline $\begin{array}{l}\text { Підвищення ефективності } \\
\text { виробництва і скорочення } \\
\text { витрат на утримання персо- } \\
\text { налу; } \\
\text { можуть одночасно виконувати } \\
\text { ряд завдань різної складності; } \\
\text { збільшення обсягів випуску } \\
\text { продукції та забезпечення } \\
\text { вищої рентабельності } \\
\text { інвестицій; } \\
\text { створення ефективної системи } \\
\text { контролю якості продукції } \\
\text { й зниження виробничих витрат } \\
\text { від браку; } \\
\text { автоматизовані системи } \\
\text { здатні працювати цілодобово } \\
\text { з незначними перервами; } \\
\text { розвиток технологій підвищу- } \\
\text { ватиме конкурентоспромож- } \\
\text { ність підприємства }\end{array}$ & $\begin{array}{l}\text { Надання технологічної } \\
\text { допомоги працівникам; } \\
\text { можуть виконувати роботу, яка } \\
\text { є надто складною або } \\
\text { небезпечною для життя людини; } \\
\text { підштовхуватимуть працівників } \\
\text { до підвищення рівня профе-- } \\
\text { сійних навичок та опанування } \\
\text { знаннями у суміжних галузях, що } \\
\text { сприятиме збільшенню фінансо- } \\
\text { вих надходжень }\end{array}$ & $\begin{array}{l}\text { Забезпечать фундаментальне при- } \\
\text { скорення науково-технологічних } \\
\text { досліджень; } \\
\text { використання новітніх технологій } \\
\text { стимулюватиме створення нових } \\
\text { робочих місць; } \\
\text { покликані заповнити брак трудових } \\
\text { ресурсів за умов незбалансовано- } \\
\text { го попиту та пропозиції на ринку } \\
\text { праці, старіння населення (старіння } \\
\text { знань і несприйняття інновацій) та } \\
\text { значних міграційних потоків квалі- } \\
\text { фікованих кадрів }\end{array}$ \\
\hline
\end{tabular}

Джерело: складено автором. 
На жаль, український ринок праці змінюється з певним запізненням. Оскільки вартість робочої сили в Україні є набагато нижчою від вартості імпортних автоматизованих машин, про стрімке зникнення ряду професій говорити ще рано. У більшості розвинутих країн ряд автоматизованих операцій виконують роботи, а в Україні вони є найбільш затребуваними за кількістю розміщених вакансій: продавці-консультанти, касири, банківські клерки, перекладачі тощо. Типові ризики, з якими український ринок праці може стикнутися уже в найближчі роки, представлені у табл. 3.

3 огляду на означені ризики та нові можливості автоматизації, ми повинні не приваблювати інвесторів дешевою робочою силою, а модернізувати й підвищувати ефективність виробництва за рахунок розширення доступу до вищої освіти. Очікується, що українці, здатні працювати з машинами, матимуть вищі шанси на працевлаштування. 3 огляду на це, професійно-технічні навчальні заклади під час підготовки випускників повинні забезпечити їх навичками роботи з автоматизованими системами, адже робітничі професії ставатимуть технологічно складнішими. На жаль, в Україні кількість закладів професійно-технічної освіти з кожним роком скорочується: 736 у 2018 р. проти 1023 у 2005 р. Перепідготовки потребуватиме і доросле населення, яке повинно бути готовим до зміни професійних обов'язків. До підтримки інноваційних проектів активно долучаються стартапери і держава. Знаковою подією для України стало масове відкриття освітніх центрів з робототехніки для дорослих і дітей: Boteon (Одеса, Дніпро, Харків, Київ, є франчайзі у восьми інших містах); «Винахідник» (Бровари, Буча, Вінниця, Київ, Львів, Дніпро, Івано-Франківськ, Харків, Одеса); TechMaker (курс для програмістів, Київ) та інші. Є курси при IT-компаніях: Guru IT School при компанії ThinkMobiles (Ужгород); Basic Robotics and Programming при Infopulse (Київ).

У 2013 р. український ринок освіти анонсував відкриття першого $M B O K$ від «Університет онлайн» (КНУ), який зібрав понад 9000 зареєстрованих користувачів. У жовтні 2014 р. стартував ще один національний освітній онлайн-проект - Prometheus, який пропонує курси з основ ведення бізнесу, інформаційної безпеки, програмування, закінчивши які слухачі отримають сертифікат, що вже набуває професійної ваги на національному ринку праці. Формат $M B O K$ в Україні успішно використовують для викладання шкільних предметів. Започаткований у 2017 р. український освітній ресурс про нові технології The Future пояснює, як завдяки технологіям майбутнього змінюється наше життя вже сьогодні. Для вибору тем автори орієнтуються на актуальні технологічні тренди. Команда проекту готує матеріали для шкіл, а вчителі використовують їх на уроках інформатики. За підтримки Міністерства освіти і науки України цим проектом успішно користуються 350 шкіл. Переклад курсів англійською мовою дав змогу запропонувати проект на ринку Канади та ряду європейських держав.

Незважаючи на певні позитивні моменти, для того, щоб український ринок праці міг належним чином слідувати світовим тенденціям та мінімізувати негативні наслідки використання автоматизованих систем, необхідним буде впровадження в дію ряду заходів. Можливими джерелами їх забезпечення повинні стати відповідні нормативно-правові документи, які регламентуватимуть правові відносини щодо політики в галузі ШІ й розвитку ринку праці, меморандуми про партнерство та пакти про приєднання до міжнародних альянсів з ШІ, угоди про співпрацю між закладами вищої освіти (ЗВО) і підприємницьким сектором, відповідні дозвільні документи щодо створення нових організаційних структур у межах ЗВО й участь у різного роду технічних проектах, державні програми фінансової підтримки технологічних нововведень тощо. Поетапність заходів повинна бути такою. 
Уряду необхідно стимулювати розвиток та поширення технологій ШІ й робототехніки шляхом створення відповідних комітетів і робочих ініціативних рад, які б займалися розробкою плану дій з розвитку інновацій. Прикладом може слугувати Дослідницький центр штучного інтелекту при Національному інституті передових промислових наук та технологій (AIST) Японії, який діє з 2015 р., а також Міністерство ШІ у ОАЕ. Необхідно суттєво збільшити державне фінансування, пов'язане 3 дослідженням ШІ завдяки зобов'язанням стосовно збільшення витрат на НДДКР та лабораторій цифрової трансформації, створення промислових і інвестиційних фондів для стартапів ШІ, інвестування в мережу та інфраструктуру, державні закупівлі, пов'язаних з ШІ.

Налагодження міжнародної співпраці у питаннях огляду проблем та вироблення рекомендацій щодо політики в галузі ШІ й розвитку ринку праці. Доволі успішними $є$ ініціативи деяких держав і регіонів світу. Першим позитивним кроком стало включення України до числа учасників стратегічної програми Європейського Союзу Horizon 2020. Однак доцільним видається налагодження й розширення співпраці у цій царині з Ізраїлем, Китаєм, Південною Кореєю, які продукують високорозвинені технології. Надання різного роду фіскальних стимулів щодо підтримки технологічних стартапів для покращення процесів організації виробництва та створення нових робочих місць. В Індії, наприклад, держава увільняє фірми-розробники програмного забезпечення від сплати прибуткового податку протягом 10 років. Ізраїльська влада постійно знижує податки для IT-компаній, підтримує спеціальну програму «Технологічні теплиці», яка надає творцям стартапу потрібне обладнання, спеціалістів та іншу допомогу. При Міністерстві управління промисловості країни існує інноваційна колегія, яка займається фінансуванням стартапів за державні кошти, надає спеціальні гранти, розмір яких може становити декілька мільйонів доларів [18].

Створення науковцям можливостей для відвідування виставок і самітів 3 ро́ботобудування, де провідні розробники обговорюють перспективи розвитку індустрії та демонструють новинки свої здобутки промислової робототехніки, роботіврятувальників, роботів-слуг та ін. Найбільше таких ініціатив належить КНР.

Відкриття великими компаніями-розробниками власних лабораторій чи курсів підготовки при кафедрах найрейтинговіших 3ВО з технічними напрямами навчання (Київський національний університет імені Тараса Шевченка, Національний університет «Львівська політехніка», Національний технічний університет України «Київський політехнічний інститут імені Ігоря Сікорського», Дніпровський національний університет). Адже саме ці навчальні заклади, згідно з опитуванням асоціації IT Ukraine, закінчили близько 40 \% програмістів України. Це треба робити, щоб студенти після закінчення навчання могли ставати до роботи, а компаніям не довелося витрачати додаткові кошти для їх перенавчання.

Запрошення до співпраці фахівців, які мають досвід роботи в $I T$-галузі, у ролі менторів, для допомоги студентам у виборі цікавих тем для навчальних проектів, долученні та організації процесу розробки програмного продукту і представлення результатів під час захисту робіт. Подібного роду ініціативи уже два роки поспіль практикує кафедра систем ШІ Інституту комп'ютерних наук та IT Національного університету «Львівська політехніка» та Львівський $I T$ Кластер.

Провести цифровізацію усіх навчальних закладів - від початкової школи до університетів. Саме таким шляхом пішла влада Китаю, оголосивши у 2017 р. план цифровізації навчальних закладів, відповідно до якого кошти, виділені на освітній сектор, повинні йти на перенавчання викладачів, упровадження класів і факультетів 
із програмування, робототехніки й ШІ, створення онлайн-платформ для індивідуального навчання, залучення інвесторів для переобладнання закладів освіти.

Міністерству освіти і науки України спільно з прогресивними представниками бізнесу варто визначити та укласти перелік затребуваних у майбутньому компетенцій, відповідно до яких треба розробляти нові навчальні курси. Збільшення кількості профільних інститутів і кафедр ШІ, робототехніки і машинознавства, які б тісно співпрацювали зі школами і приватними технохабами з метою залучення технологічних талантів до комплексного дослідження систем ШІ, результати яких впроваджувалися б у різних сферах. Це дасть змогу університетській освіті виконувати роль агента соціальних інновацій. Нині в Україні діє лише дві такі установи: Інститут проблем штучного інтелекту МОН України та НАН України, та Інститут інформатики і штучного інтелекту ДонНТУ.

Організація літніх шкіл з вивчення $I T$-технологій та участь наших школярів і студентів проектах за кордоном - на кшталт DataLab SummerCamp 2016 у Празі, Mitacs Globalink Research Internship Program у Канаді. Першопрохідцем в Україні стала Перша міжнародна весняна школа з верифікації та штучного інтелекту, яка відкрилась на базі Харківського національного університету радіоелектроніки у квітні 2018 р.

Нам необхідно наслідувати європейські практики щодо підтримки неформальної освіти, яка має готувати до швидких змін. Це давно підтримувана європейськими державами концепція освіти протягом життя у вигляді тренінгів, семінарів, масових відкритих онлайн-курсів тощо. Навчальним закладам треба підтримати ініціативи з упровадження у закладах вищої освіти курсів Coursera, Edx, Udemy, Udasity для навчання українських студентів за світовими програмами та розроблення власних онлайн-курсів. Основною перевагою українських $M B O K$ повинна стати орієнтація на інноваційні футуристичні напрями і спеціалізації, які дадуть змогу підготувати затребуваних ринком праці спеціалістів. Мова йде про популярні курси з машинного навчання і комп’ютерної графіки, ШІ, генної інженерії, розвитку біотехнологій і мов програмування тощо.

Запровадження стипендій для обдарованої молоді та академічної спільноти, які займаються дослідженнями у сфері ШІ. Так, уряд США запровадив стипендію Turing, щоб підтримати початкову когорту стипендіатів ШІ, а Китай запустив п'ятирічну університетську програму для навчання як мінімум 500 вчителів та 5000 студентів, що працюють над технологіями.

Необхідно краще інформувати молодь та академічну спільноту про освітні ініціативи технологічних компаній. Найбільшою їх кількістю відома компанія Google, яка 2018 року запустила безкоштовний курс Learn with Google AI, присвячений машинному навчанню. Це ресурс, за допомогою якого будь-хто може дізнатися про розвиток можливостей ШІ, свої поліпшити власні навички і застосовувати їх у щоденній практиці. Подібного роду ініціативи з 2016 р. просуває на український ринок освіти і IT-школа Samsung, намагаючись зацікавити старшокласників прогресивними професіями майбутнього. Ці проекти активно підтримує Інститутом модернізації змісту освіти в рамках концепції нової української школи. Державним і приватним ЗВО треба кооперуватися з європейськими університетами в сфері ШІ для кращого обміну напрацюваннями.

Висновки. Вирішити завдання автоматизації уряд країни зможе через реорганізацію системи освіти, iї цифровізацію, підтримання ініціатив з популяризації курсів глобальних провайдерів, упровадження активних систем дуальної та технологічної освіти. Необхідність долучення до урядових ініціатив корпоративного сектору пов'язана 3 можливістю отримання професійних навичок, які будуть затребувані футуристичними 
професіями та виведенню відносин найму на новий рівень. Нормативно-правова та фінансова підтримка уряду сприятимуть розв'язанню соціально-економічних проблем, динамічному розвитку пріоритетних галузей економіки, покращенню процесів організації виробництва й підготовці потрібних фахівців, установленню міри відповідальності за дотримання цільових показників щодо створення «цифрових» робочих місць, а використання нових комбінацій співпраці державно-приватних і наукових кіл - майбутньому технологічному лідерству країни.

\section{ЛІТЕРАТУРА}

1. Smith B., Shum H. The Future Computed Artificial Intelligence and its role in society.- Published by Microsoft Corporation Redmond, Washington. U.S.A., 2018. - 151 p.

2. Мулявка В. Нові технології і глобальна нерівність // СПІЛЬНЕ: журнал соціальної критики. -12 жовт. 2016 [Електронний ресурс] - Режим доступу: https://commons.com.ua/uk/novi-tehnologiyii-globalna-nerivnist/ (дата звернення: 18.12.2018).

3. Новак I. Стратегія зайнятості для України: якими мають бути орієнтири? // Дзеркало тижня: міжнародний громадський тижневик. - Вип. 43, 20 листоп. 2017 [Електронний ресурс] - Режим доступу: https://dt.ua/macrolevel/strategiya-zaynyatosti-dlya-ukrayini-yakimi-mayut-buti-oriyentiri260541 .html (дата звернення: 18.12.2018).

4. Бріньолфссон Е., МакАфі Е. Друга епоха машин. - K., Fund, 2016. - 236 p.

5. Форд М. Пришестя роботів. Техніка і загроза майбутнього безробіття / Пер. $з$ англ. В. Горбатька. - Київ: Наш формат, 2016. - 400 с.

6. Future of work and skills. $2^{\text {nd }}$ Meeting of the G20 Employment Working Group (15-17 February 2017). - Hamburg, Germany: Organisation for Economic Co-operation and Development (OECD), 2017. $-24 \mathrm{p}$.

7. A future that works: automation, employment, and productivity. Executive summary. - McKinsey \& Company, 2017. $-21 \mathrm{p}$.

8. Hawksworth J., Berriman R. Will robots really steal our jobs? An international analysis of the potential long term impact of automation. - PricewaterhouseCoopers LLP, 2018. - $44 \mathrm{p}$.

9. Robotic Industries Association (RIA) [Електронний ресурс]. - Режим доступу: https://www. automationworld.com/company/robotic-industries-association-ria (дата звернення: 22.11.2018).

10. Global Robotics Market 2018-2022. Report. - TechNavio, 2018. - 132 p.

11. Китай став найбільшим у світі споживачем промислових роботів - Асоціація українсько-китайського співробітництва. - 04.08.2017. [Електронний ресурс]. - Режим доступу: http://aucc. org.ua/uk/kitay-stav-naybilshim-u-sviti-spozhivachem-promislovih-robotiv/ (дата звернення 28.11. 2018).

12. The Future of Jobs Report 2018. Centre for the New Economy and Society. - Geneva: World Economic Forum, 2018. - $147 \mathrm{p}$.

13. Why India ranks among the top 3 countries in AI skills. [Електронний ресурс]. - Режим доступу: https://www.livemint.com/AI/u8hvUi7qObOLP7Shq4rB1M/Why-India-ranks-among-the-top-3countries-in-AI-skills.html (дата звернення: 09.11.2018)

14. Тривожне майбутнє: біохакери, космічні гіди та клас «непотрібних». - 27 липня 2017 [Електронний ресурс]. - Режим доступу: https://www.volynnews.com/news/society/tryvozhne-maybutnyebiokhakery-kosmichni-hidy-ta-klas-nepotribnykh/ (дата звернення: 08.10.2018)

15. Robots will destroy our jobs - and we're not ready for IT - Guardian News and Media Limited. - 2017 [Електронний ресурс]. - Режим доступу: https://www.theguardian.com/technology/2017/jan/11/ robots-jobs-employees-artificial-intelligence (Last accessed: 04.11.2018).

16. Kahn J. Sky-High Salaries Are the Weapons in the AI Talent War. - Bloomberg Businessweek, - 2018 [Електронний ресурс]. - Режим доступу: https://www.bloomberg.com/news/articles/2018-02-13/ in-the-war-for-ai-talent-sky-high-salaries-are-the-weapons (Дата звернення: 04.11.2018).

17. McAfee A., Brynjolfsson E. Machine, Platform, Crowd: Harnessing Our Digital Future. -W.W. Norton \& Company, 1 ed, 2017. -408 p. 
18. Друга IT-столиця світу. Як Ізраїль став одним із найбільших технологічних центрів планети // Expres.ua. - 2018. [Електронний ресурс]. - Режим доступу: https://expres.online/archive/news/ 2018/01/19/280984-druga-it-stolycya-svitu-izrayil-stav-odnym-naybilshyh-tehnologichnyh-centriv (дата звернення: 12.12.2018).

\section{REFERENCES}

1. Smith, B., Shum, H. (2018). The Future Computed Artificial Intelligence and its role in society. Published by Microsoft Corporation Redmond, Washington. U.S.A.

2. Muliavka V. (2016) Novi tekhnolohii i hlobalna nerivnist [New technologies and global inequality]. SPILNE: zhurnal sotsialnoi krytyky. Access mode: https://commons.com.ua/uk/novi-tehnologiyi-i-globalnanerivnist/ [in Ukrainian].

3. Novak I. (2017) Stratehiia zainiatosti dlia Ukrainy: yakymy maiut buty oriientyry? [Employment strategy for Ukraine: what should the benchmarks be?]. Dzerkalo tyzhnia: mizhnarodnyi hromadskyi tyzhnevyk. Access mode: https://dt.ua/macrolevel/strategiya-zaynyatosti-dlya-ukrayini-yakimi-mayut-butioriyentiri-260541_.html [in Ukrainian].

4. Brignolpson, E., McAfee, A. (2016). Druha epokha mashyn [Second era of cars]. K. Fund [in Ukrainian].

5. Ford, M. (2016). Pryshestia robotiv. Tekhnika i zahroza maibutnoho bezrobittia [The advent of robots. Technique and the threat of future unemployment]. Pereklad z anhliiskoi V. Horbatka. Kyiv: Nash format [in Ukrainian].

6. Future of work and skills. $2^{\text {nd }}$ Meeting of the G20 Employment Working Group (15-17 February 2017). Hamburg, Germany: Organisation for Economic Co-operation and Development.

7. A future that works: automation, employment, and productivity. Executive summary (2017). McKinsey \& Company.

8. Hawksworth, J., Berriman R. (2018). Will robots really steal our jobs? An international analysis of the potential long term impact of automation. Pricewater house Coopers LLP.

9. Robotic Industries Association (RIA) (2018). https://www.automationworld.com/company/roboticindustries-association-ria.

10. Global Robotics Market 2018-2022. Report (2018). TechNavio.

11. Kytai stav naibilshym u sviti spozhyvachem promyslovykh robotiv [China has become the world's largest consumer of industrial robots]. Asotsiatsiia ukrainsko-kytaiskoho spivrobitnytstva. http://aucc.org.ua/ uk/kitay-stav-naybilshim-u-sviti-spozhivachem-promislovih-robotiv/ [in Ukrainian].

12. The Future of Jobs Report 2018. Centre for the New Economy and Society (2018). Geneva: World Economic Forum.

13. Why India ranks among the top 3 countries in AI skills (2018). https://www.livemint.com/AI/ u8hvUi7qObOLP7Shq4rB1M/Why-India-ranks-among-the-top-3-countries-in-AI-skills.html.

14. Tryvozhne maibutnie: biokhakery, kosmichni hidy ta klas «nepotribnykh» [An alarming future: biohackers, space guides and a «unnecessary» class] (2017). https://www.volynnews.com/news/society/ tryvozhne-maybutnye-biokhakery-kosmichni-hidy-ta-klas-nepotribnykh/ [in Ukrainian].

15. Robots will destroy our jobs - and we're not ready for IT (2017). Guardian News and Media Limited. https://www.theguardian.com/technology/2017/jan/11/robots-jobs-employees-artificialintelligence.

16. Kahn J. (2017). Sky-High Salaries Are the Weapons in the AI Talent War. Bloomberg Businessweek. https://www.bloomberg.com/news/articles/2018-02-13/in-the-war-for-ai-talent-sky-high-salariesare-the-weapons

17. McAfee, A., Brynjolfsson, E. (2017). Machine, Platform, Crowd: Harnessing Our Digital Future. Publisher: W. W. Norton \& Company; 1 edition.

18. Druha IT-stolytsia svitu. Yak Izrail stav odnym iz naibilshykh tekhnolohichnykh tsentriv planet [The second IT capital of the world. How Israel became one of the largest technological centers of the planet] (2018). https://expres.online/archive/news/2018/01/19/280984-druga-it-stolycya-svitu-izrayil-stav-odnymnaybilshyh-tehnologichnyh-centriv [in Ukrainian].

Стаття надійшла до редакції журналу 18.12.2018. 